\title{
Correction: The existence of solutions for systems of generalized set-valued nonlinear quasi-variational inequalities
}

\author{
Yang-Qing Qiu ${ }^{1,2^{*}}$, Xiao-Ling Li ${ }^{3}$ and Lu-Chuan Ceng ${ }^{1}$
}

\section{"Correspondence:}

qiuyangqing@sohu.com

'Department of Mathematics,

Shanghai Normal University,

Shanghai, 200234, P.R. China

${ }^{2}$ College of Applied Science, Jiangxi

University of Science and

Technology, Ganzhou, Jiangxi

341000 , P.R. China

Full list of author information is

available at the end of the article

\section{The correction of affiliation in [1]}

The affiliation: Department of Mathematics, Shanghai Normal University, Shanghai, 200234 , is added to the author information for Yang-Qing Qiu.

\section{The correction of contribution in [1]}

Dr. Lu-Chuan Ceng is added as the third author. Dr. Ceng's information is as follows: "Department of Mathematics, Shanghai Normal University, Shanghai, 200234, P.R. China".

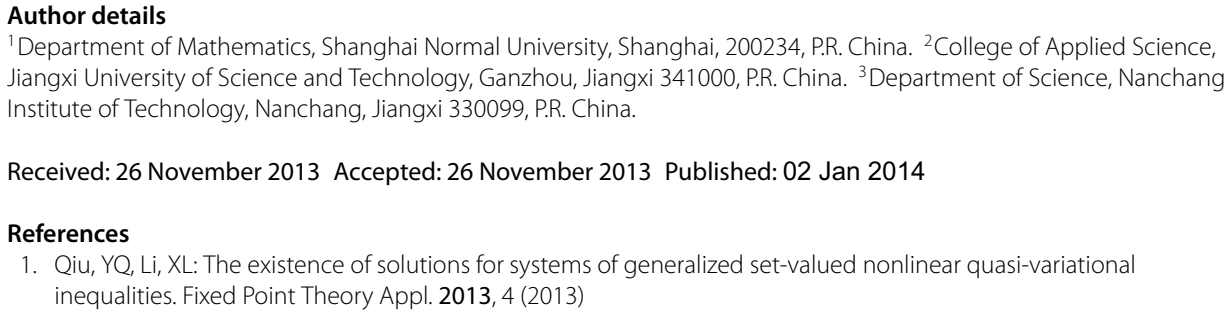

'Department of Mathematics, Shanghai Normal University, Shanghai, 200234, P.R. China. ${ }^{2}$ College of Applied Science, Jiangxi University of Science and Technology, Ganzhou, Jiangxi 341000, P.R. China. ${ }^{3}$ Department of Science, Nanchang Institute of Technology, Nanchang, Jiangxi 330099, P.R. China.

Received: 26 November 2013 Accepted: 26 November 2013 Published: 02 Jan 2014

References

1. Qiu, YQ, Li, XL: The existence of solutions for systems of generalized set-valued nonlinear quasi-variational inequalities. Fixed Point Theory Appl. 2013, 4 (2013)

10.1186/1687-1812-2014-2

Cite this article as: Qiu et al.: Correction: The existence of solutions for systems of generalized set-valued nonlinear quasi-variational inequalities. Fixed Point Theory and Applications 2014, 2014:2

\section{Springer}

○2014 Qiu et al: licensee Springer. This is an Open Access article distributed under the terms of the Creative Commons Attribution License (http://creativecommons.org/licenses/by/2.0), which permits unrestricted use, distribution, and reproduction in any medium, provided the original work is properly cited.
Submit your manuscript to a SpringerOpen ${ }^{\circ}$ journal and benefit from:

- Convenient online submission

Rigorous peer review

- Immediate publication on acceptance

- Open access: articles freely available online

- High visibility within the field

Retaining the copyright to your article

Submit your next manuscript at springeropen.com 